\title{
Microrelief of Rounded Diamond Crystals as an Indicator of the Redox Conditions of Their Resorption in a Kimberlite Melt
}

\author{
Alexander F. Khokhryakov ${ }^{1,2, *}$, Denis V. Nechaev ${ }^{1}$ and Alexander G. Sokol ${ }^{1,2}$ \\ 1 Sobolev Institute of Geology and Mineralogy SB RAS, Koptyug ave. 3, 630090 Novosibirsk, Russia; \\ nechaev@igm.nsc.ru (D.V.N.); asokol@igm.nsc.ru (A.G.S.) \\ 2 Department of Geology and Geophysics, Novosibirsk State University, 630090 Novosibirsk, Russia \\ * Correspondence: khokhr@igm.nsc.ru; Tel.: +7-383-330-7501
}

Received: 25 February 2020; Accepted: 20 March 2020; Published: 23 March 2020

\begin{abstract}
We conducted a detailed study of the morphology of diamond crystals partially dissolved in a water-bearing kimberlite melt at pressure of $6.3 \mathrm{GPa}$, temperature of $1400^{\circ} \mathrm{C}$, and two oxygen fugacities $\left(\mathrm{fO}_{2}\right)$ corresponding to the $\mathrm{Re}-\mathrm{ReO}_{2}$ buffer and near the magnetite-hematite $(\mathrm{MH})$ buffer. The triangular etch pits on the $\{111\}$ faces, which formed during experimental diamond dissolution, were found to completely correspond to negative trigons on natural diamond crystals in the shape and sidewalls inclination angle. Furthermore, two experimental $\mathrm{fO}_{2}$ values were associated with two relief types of the rounded tetrahexahedroid surfaces typical of natural rounded diamonds. Therefore, the surface microrelief on rounded natural diamond crystals was concluded to be an indicator of the redox conditions of natural diamond resorption.
\end{abstract}

Keywords: diamond; resorption; crystal morphology; kimberlite melt; high-pressure; high-temperature

\section{Introduction}

At present, no one doubts that the round shape and most surface patterns of natural diamond crystals were formed during the natural resorption process. Natural diamond resorption is supposed to occur in kimberlite magma during diamond transportation from the mantle to the Earth's surface [1-4]. To date, there is no universal primary kimberlite melt model. The occurrence of silicate-carbonate melt inclusions trapped in megacrysts at different stages of kimberlite magma evolution, confirm that kimberlites magmas are carbonated melts [5]. Most researchers believe that the characteristic features of the composition of primary kimberlite magma are high $\mathrm{MgO}$ concentrations, but relatively small amounts of $\mathrm{SiO} 2(25-35 \mathrm{wt} \%), \mathrm{Al} 2 \mathrm{O} 3$, and alkalis [6-8]. Kamenetsky et al. [9,10] believes that primary magma was almost anhydrous rich alkalis and halogens carbonate melt. Despite the contradictions, there is consensus in the literature that unique the unserpentinized units of the Udachnaya-East kimberlite may represent an example of "pristinely preserved" kimberlite. Thus, the Udachnaya-East kimberlite can act as an adequate model of primary kimberlite melt. It should be noted that kimberlite melts can be not only a medium for the resorption of diamond, but also for its crystallization [11,12]. Based on experimental data, the conditions of natural resorption of diamond were reconstructed, under which rounded forms of diamond crystals are formed. These forms were shown to emerge upon dissolution of plane-faced diamond crystals in water-bearing carbonate, silicate, and carbonate-silicate melts, or fluids in a wide range of temperatures $\left(1100-1500^{\circ} \mathrm{C}\right)$ and pressures (1.0-6.3 GPa) [13-20]. However, despite similar macromorphology of natural rounded diamonds, their surfaces have different reliefs. The relief is determined by the presence of trigons, serrate and shield-shaped laminae, shagreen, 
drop-like hillocks, and many other patters. Only, for some of these elements of the rounded diamond microrelief, the formation conditions were determined. A number of surface relief elements are unambiguously associated with the features of the internal diamond structure. It has been found that trigons on the $\{111\}$ faces are located at the dislocation outputs [21-24], and the intersecting striation is associated with plastic deformation bands [3]. Drop-like hillocks forming shagreen or block-type relief of rounded surfaces occur at sites of strong lattice deformation in diamond crystals [25]. Some microrelief elements are associated with conditions of natural diamond resorption. Orientation of trigons at high pressures was demonstrated to be controlled by two oxygen fugacities $\left(\mathrm{fO}_{2}\right)$ and process temperature [26] as well as $\mathrm{CO}_{2}\left(\right.$ or $\mathrm{CO}_{3}{ }^{2+}$ ) content in resorption medium $[18,27,28]$. Comparison of diamonds resorbed at pressures of 1-3 GPa and 5-6 GPa in media of similar composition did not reveal any fundamental differences between them. In both cases, glossy, low relief surfaces with negatively oriented trigons and ditrigonal layers on the $\{111\}$ faces were formed $[14,15,18,29]$.

In the previous experimental study on simulation of primary kimberlite melt composition, we investigated the specificity of diamond resorption by these melts [19]. Different oxygen fugacity in the melts was shown to correlate with a difference in the morphology of diamond dissolution. In general, diamond dissolution was accompanied by the formation of shield-shaped laminae, trigons on the $\{111\}$ faces, and rounded tetrahexahedroid surfaces at the octahedron edges. However, the tetrahexahedroid surfaces were significantly different. They had fine striation in the case of $\mathrm{fO}_{2}$ controlled by $\mathrm{Re}-\mathrm{ReO}_{2}$ buffer, but had rounded elements at more oxidized conditions in the case of $\mathrm{fO}_{2}$ between $\mathrm{Re}-\mathrm{ReO}_{2}$ and $\mathrm{Fe}_{3} \mathrm{O}_{4}-\mathrm{Fe}_{2} \mathrm{O}_{3}(\mathrm{MH})$ buffers. However, Sokol et al. [19] did not study diamond resorption forms in detail. Therefore, the presented work provides a detailed study of the microrelief of crystals produced in the Ud4, Ud5, and Ud6 experiments [19]. The greatest attention has been paid to the microrelief of rounded tetrahexahedroid surfaces and $\{111\}$ faces, namely, to the striation pattern, shape of layers, and features of trigonal etch pits.

\section{Materials and Methods}

We studied nine diamond crystals produced earlier in experiments with a water-bearing kimberlite melt [19]. The characteristics of starting materials, design of the high-pressure cell, and experimental procedure were in detail described earlier [19]. Here, we only report the main parameters and experimental conditions. Experiments were performed using a multi-anvil, split-sphere apparatus at a pressure of $6.3 \mathrm{GPa}$, a temperature of $1400{ }^{\circ} \mathrm{C}$, and a run time of $10 \mathrm{~h}$. The mixture consisted of powder of fresh group I kimberlite from the Udachnaya-East pipe in Yakutia and distilled water added with a micro-syringe before the final ampoule assembly. Before the experiments, kimberlite was cleaned from xenogenic material and had the following composition ( $\mathrm{wt} \%$ ): $\mathrm{SiO}_{2}-27.52, \mathrm{TiO}_{2}-1.35, \mathrm{Cr}_{2} \mathrm{O}_{3}-0.12$, $\mathrm{Al}_{2} \mathrm{O}_{3}-2.93, \mathrm{Fe}_{2} \mathrm{O}_{3}-3.10, \mathrm{FeO}-5.04, \mathrm{MnO}-0.15, \mathrm{MgO}-27.68, \mathrm{NiO}-0.21, \mathrm{CaO}-13.32, \mathrm{Na}_{2} \mathrm{O}-2.56, \mathrm{~K}_{2} \mathrm{O}-1.84$, $\mathrm{P}_{2} \mathrm{O}_{5}-0.41, \mathrm{H}_{2} \mathrm{O}-2.49, \mathrm{CO}_{2}-9.43, \mathrm{~S}-0.33, \mathrm{~F}-0.14$, and $\mathrm{Cl}-1.32$; total-99.94. Three octahedral crystals of natural diamond from kimberlite pipes Udachnaya and Aikhal (Yakutia) were used in each experiment. The crystals were colorless, without inclusions and cracks visible under an optical microscope, with flat $\{111\}$ faces, and without signs of natural resorption.

In the experiments, double-capsule assembly were used to control oxygen volatility: An internal $\mathrm{Pt}$ ampoule containing sample was enclosed in an external container made of a $\mathrm{NiO}+\mathrm{CsCl}$ mixture (without addition of water). The Pt capsules were lined with Re foil in order to prevent Fe loss and to fix $\mathrm{fO}_{2}$ in the sample. External $\mathrm{NiO}+\mathrm{CsCl}$ containers, due to their low $\mathrm{fH}_{2}$, ensured hydrogen outflow from $\mathrm{Pt}$ ampoules with water-bearing samples, which led to their oxidation to a level controlled by the $\mathrm{Re}-\mathrm{ReO}_{2}$ equilibrium. Therefore, oxygen fugacity upon partial oxidation of Re foil (run Ud-6) corresponded to the $\mathrm{Re}-\mathrm{ReO}_{2}$ buffer, which is about one to two log units above the NNO buffer [19]. In the second case, platinum ampoules without Re foil were used (runs Ud-4 and Ud-5). The loss of iron from the kimberlite melt due to its diffusion into platinum amounted to $19 \%-28 \%$ in these experiments [19]. As shown by Brey et al. [30], significant efflux of Fe to the Pt ampoule was accompanied by oxidation of samples, up to $\mathrm{fO}_{2}$ of the magnetite-hematite (MH) buffer. Given these 
data, it may be concluded that diamond dissolution in experiments with $\mathrm{Pt}$ ampoules without Re foil (runs Ud-4 and Ud-5) occurred under more oxidizing conditions in the $\mathrm{fO}_{2}$ interval between $\mathrm{Re}-\mathrm{ReO}_{2}$ and $\mathrm{MH}$ buffers. This was evidenced by the fact that diamond resorption rates in $\mathrm{Pt}$ ampoules without Re foil was 1.2-1.4-fold higher than that in ampoules with Re foil. The results of experiments on diamond dissolution are shown in Table 1.

Table 1. Conditions and results of experiments on the dissolution of diamond in the kimberlite melt at $6.3 \mathrm{GPa}, 1400{ }^{\circ} \mathrm{C}$, and duration of $10 \mathrm{~h}$.

\begin{tabular}{|c|c|c|c|c|c|}
\hline \multirow[b]{2}{*}{ Run No } & \multirow{2}{*}{$\begin{array}{l}\mathrm{H}_{2} \mathrm{O} \\
\text { wt \% }\end{array}$} & \multirow[b]{2}{*}{$\mathrm{fO}_{2}$} & \multicolumn{3}{|c|}{ Diamonds } \\
\hline & & & $\begin{array}{l}\text { Initial Weight, } \\
\text { mg }\end{array}$ & $\begin{array}{c}\text { Weight Loss, } \\
\text { mg }\end{array}$ & $\begin{array}{l}\text { Dissolution } \\
\text { Rate, mg/h }\end{array}$ \\
\hline $\mathrm{Ud}-4$ & 10 & $\mathrm{Re}-\mathrm{ReO}_{2}<\mathrm{fO}_{2}<\mathrm{MH}$ & 1.02 & 0.20 & 0.02 \\
\hline $\mathrm{Ud}-5$ & 12 & $\mathrm{Re}-\mathrm{ReO}_{2}<\mathrm{fO}_{2}<\mathrm{MH}$ & 1.02 & 0.24 & 0.024 \\
\hline Ud-6 & 12 & $\mathrm{Re}-\mathrm{ReO}_{2}$ & 1.12 & 0.17 & 0.017 \\
\hline
\end{tabular}

Before the study, diamond crystals were first treated with a hot mixture of nitric and hydrochloric acids (1:3 volume ratio). Further, to remove possible organic contaminants, diamonds were treated in a hot mixture of concentrated $\mathrm{H}_{2} \mathrm{SO}_{4}$ and a $30 \% \mathrm{~K}_{2} \mathrm{Cr}_{2} \mathrm{O}_{7}$ aqueous solution (3:2 volume ratio). Diamonds were washed by boiling in distilled water after each acid treatment.

Diamond crystals were studied by optical microscopy using a Carl Zeiss Axio Imager Z2m optical microscope (Carl Zeiss Microscopy, Jena, Germany). The differential-interference contrast (DIC) method was used to increase the contrast of the image of the faces relief.

The total interference contrast (TIC) method was used to generate cross-section profiles of shallow etch pits. Deep etch pits were measured using a MII-4 double-reflecting interference microscope (LOMO, Saint Petersburg, Russia). The error in determining the inclination angles of deep pits was estimated at $\pm 5^{\prime}$. Scanning electron microscopy (SEM) of crystals was performed on a Tescan MIRA3 LMU microscope ((Tescan, Brno, Czech Republic) at the Analytical Center for the Multi-Elemental and Isotope Research of the Siberian Branch of the Russian Academy of Sciences.

\section{Results}

After the experiments, loss of diamond weight ranged from 15\% (Ud-6) to $24 \%$ (Ud-5). Crystals significantly changed their initial octahedral shape. Rounded stepped surfaces formed at the octahedron edges. The initial $\{111\}$ faces were significantly reduced and sculptured by etch pits and shield-shaped or ditrigonal laminae. Large and deep etch channels formed on most crystals. Figure 1 shows SEM photographs of typical diamond crystals after the experiments. Even a quick look at the crystals reveals significant differences in the morphology of diamond dissolution forms produced in a water-bearing kimberlite melt under conditions controlled by $\mathrm{Re}-\mathrm{ReO}_{2}$ buffer (Figure $1 \mathrm{a}, \mathrm{b}$ ) and under more oxidizing conditions (Figure 1c,d). These differences are manifested primarily in different sculptures on newly formed rounded surfaces and in a different number of etch pits.

We focused our study on these two relief types of diamond crystals. All faces of each diamond crystal were examined under an optical microscope using the DIC method. Similarly, all crystals were tested in different orientations using a scanning electron microscope (Figure 1). The most representative $\{111\}$ crystal faces and stepped surfaces were investigated by the TIC method using an optical microscope. Sizes of all detected etch pits were determined, and 40 measurements of the etch pit sidewalls inclination angle relative to the $\{111\}(\alpha(111))$ faces were made. 

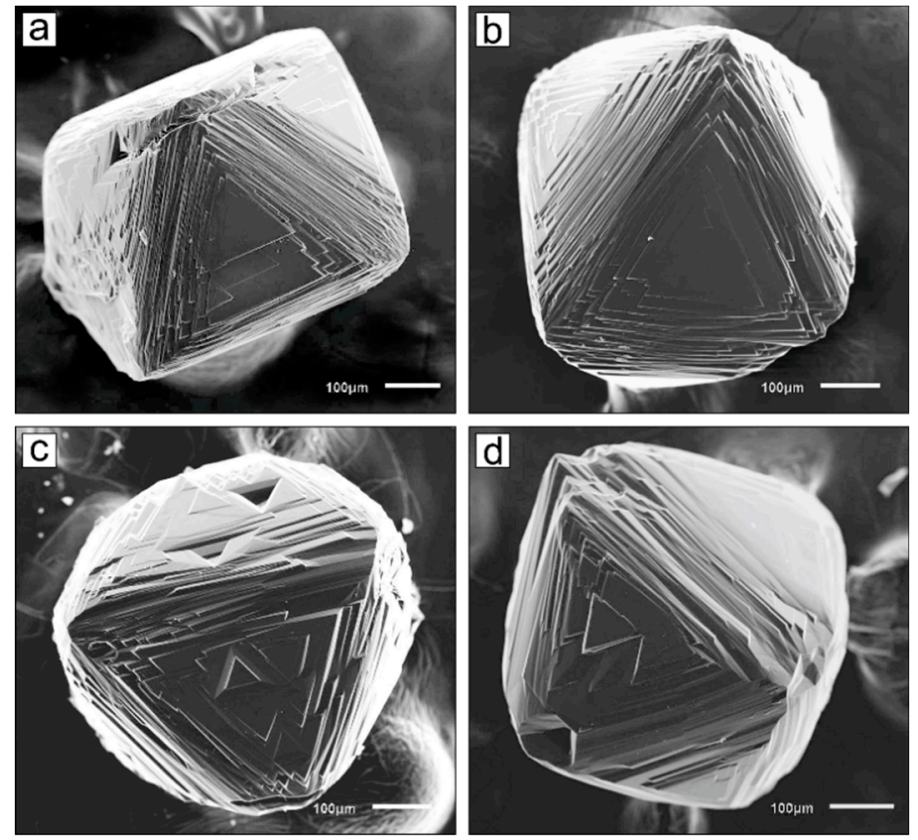

Figure 1. SEM micrographs of diamond crystals after dissolution runs in kimberlite melt at different two oxygen fugacities $\left(\mathrm{fO}_{2}\right)$ : (a,b) run $\mathrm{Ud}-6$; (c) run Ud-4; and (d) run Ud-5.

\section{1. $\{111\}$ Faces}

The main relief elements of $\{111\}$ faces are triangular etch pits and ditrigonal (or shield-shaped) layers. Large layers outlining the $\{111\}$ faces have an almost triangular shape (Figures 1 and 2). The obtuse angles of the ditrigonal layers are directed to the octahedron edges and have values of approximately $175^{\circ}$. The acute angles of these layers are directed to the octahedron vertexes and have values of approximately $65^{\circ}$. The shape of the layers change toward the center of the $\{111\}$ faces. The layers have an almost hexagonal shape in the central parts of $\{111\}$ faces (Figure 2c). Near the $<100>$ vertices, the polycentric development of the layers led to the formation of serrate surfaces.
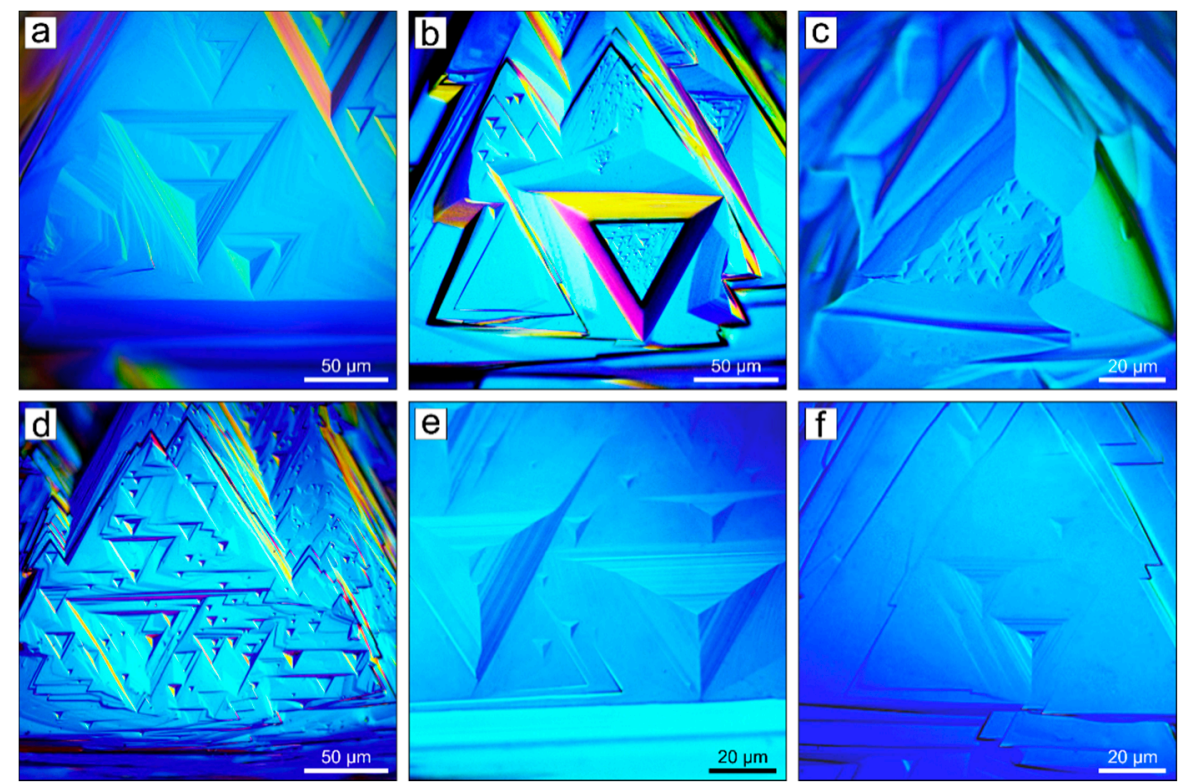

Figure 2. Optical micrographs (differential-interference contrast (DIC) method) of $\{111\}$ faces of diamond crystals: $(\mathbf{a}-\mathbf{c})$ run Ud-5; (d-f) run Ud-6. 
Etch pits on the $\{111\}$ faces have a triangular contour that is oriented $180^{\circ}$ relative to the $\{111\}$ faces (Figure 2). In accordance with the terminology used to describe the morphology of natural diamond, we call these etch pits as negative trigons [31]. Two types of trigons are found on the studied crystals. Trigons of the first type have a non-truncated pyramidal shape and are called pyramidal and point-bottomed trigons, or, short, p.b.trigons. Another trigon type is a truncated triangular pyramid, i.e., it has a flat base (bottom) parallel to the $\{111\}$ face. They are called flat-bottomed trigons, or, in short, f.b.trigons. We will use this terminology in the rest of the paper.

Figure 2 shows the most representative images of trigons found on the $\{111\}$ faces. Most trigons are symmetrical and from a few to $100 \mu \mathrm{m}$ in size. The walls of large trigons are usually stepped to varying degrees and, therefore, have a variable inclination to the $\{111\}$ face in most cases. Visual examination under an optical microscope reveals lighter trigons with sloping walls. These trigons include all p.b.trigons and small f.b.trigons. Most large f.b.trigons have dark sidewalls, which indicates their steeper inclinations to the $\{111\}$ face.

Trigonal sidewall inclination angles $\left(\alpha_{(111)}\right)$ were determined using the TIC method. Figure 3 shows typical trigon profiles. The inclination angles of shallow p.b.trigons and f.b.trigons range from $0.5^{\circ}$ to $3.5^{\circ}$. Steep non-stepped (or thin-stepped) f.b.trigons have $\alpha_{(111)}$ of about $10^{\circ}$. No differences were found in the angles of $\alpha_{(111)}$ trigons on diamond crystals dissolved at various $\mathrm{fO}_{2}$ values.
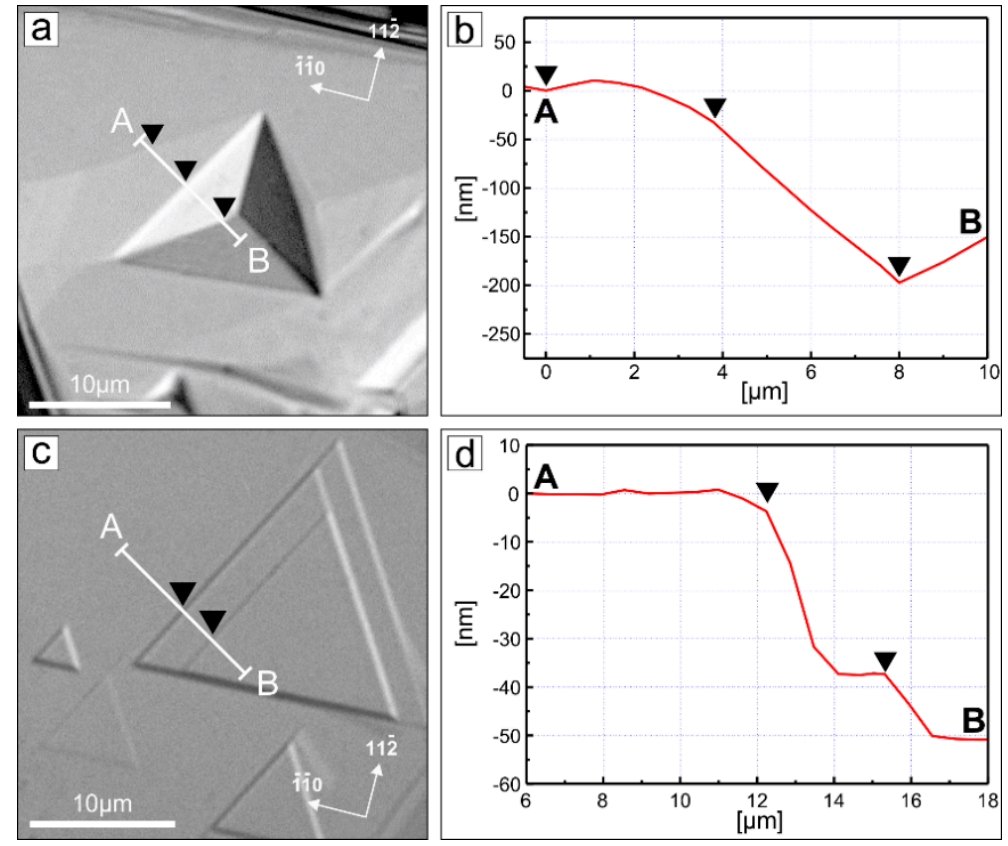

Figure 3. DIC images and cross-sectional profiles of typical trigons on the $\{111\}$ faces of diamond crystals: (a) point-bottomed trigon; (b) cross-section profile of the trigon shown in Figure 3a; (c) flat-bottomed trigons; and (d) cross-section profile of the trigon shown in Figure 3c.

The histograms shown in Figure 4 show the size distribution of p.b.trigons and f.b.trigons on the $\{111\}$ faces of six diamond crystals. Three crystals are partially dissolved at $\mathrm{fO}_{2}$ of the $\mathrm{Re}-\mathrm{ReO}_{2}$ buffer (run Ud-6), and three crystals are partially dissolved under more oxidized conditions, near the $\mathrm{MH}$ buffer (run Ud-5). On diamonds from run U-6, the predominant type is p.b.trigons accounting for $87 \%$ of the total trigons. Their maximum size reaches $50 \mu \mathrm{m}$, but prevailing p.b.trigons $(96 \%)$ are less than $15 \mu \mathrm{m}$ in size (Figure 4c). Flat-bottomed trigons are less numerous. Mainly, these are not deep trigons, no larger than $35 \mu \mathrm{m}$ in size (Figure 4d). On diamonds from run Ud-5, the number of both trigon types is approximately the same and is $55 \%$ for p.b.trigons and $45 \%$ for f.b.trigons. Unlike run Ud-6, pyramidal trigons are smaller. Most of them (96\%) are less than $10 \mu \mathrm{m}$ in size (Figure 4a). In addition, unlike run Ud-6, the dimensions of f.b.trigons demonstrate a distinctive bimodal distribution, 
indicating the presence of two f.b.trigon types (Figure $4 b$ ). Relatively small f.b.trigons (with a maximum at $5 \mu \mathrm{m}$ ) have shallow walls. Large f.b.trigons, ranging from 30 to $100 \mu \mathrm{m}$ in size and with a maximum of $60-70 \mu \mathrm{m}$, have steeper walls.
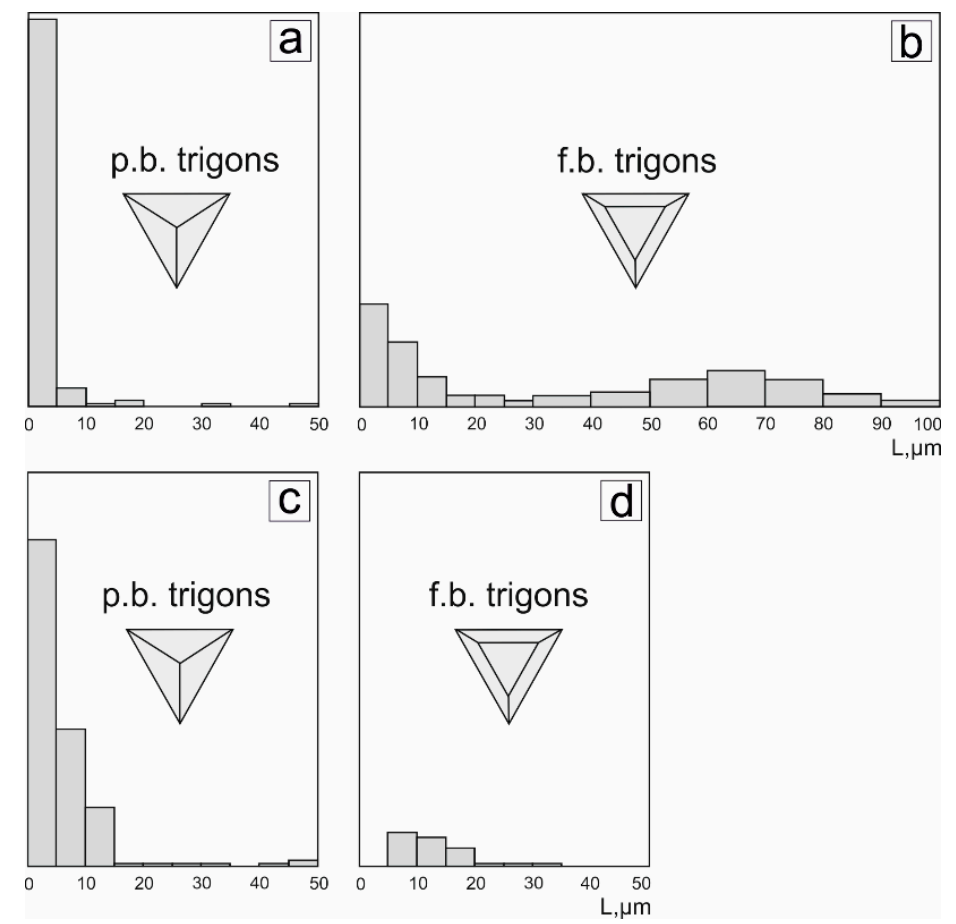

Figure 4. Histograms of the sizes of trigons on the (111) faces of diamond crystals dissolved under various conditions: $(\mathbf{a}, \mathbf{b})$ under oxidizing conditions in the $\mathrm{fO}_{2}$ interval between $\mathrm{Re}-\mathrm{ReO}_{2}$ and magnetite-hematite (MH) buffers (runs Ud-4 and Ud-5); (c,d) under conditions of the Re-ReO $\mathrm{O}_{2}$ buffer (run Ud-6).

\subsection{Rounded Surfaces at Octahedron Edges}

As already noted, curved rough-relief surfaces formed in place of the octahedron edges. They are characterized by a significant curvature in the direction of $\{111\}$ faces and an insignificant curvature in the direction of $<100>$ vertices (Figure 1). In the central part of the surfaces, there is a break in the form of a curved line (pseudo-edge) connecting the adjacent $\{111\}$ faces (Figure $5 c, d$ ). These pseudo-edges are most clearly seen on the rounded surfaces of diamonds from Ud-4 and Ud-5 experiments (Figure $5 c, d$ ).

Among natural rounded diamonds, these crystals are called tetrahexahedroids or, more often, dodecahedroids. Depending on the redox conditions used in our experiments, the structure of these curved surfaces is significantly different. Diamond dissolution under redox conditions controlled by $\mathrm{Re}-\mathrm{ReO}_{2}$ buffer (run 6) led to the formation of rounded stepped surfaces with relatively uniform parallel striation (Figure $5 a, b$ ). Near the $<100>$ vertices, parallel striation turns into serrate striation. A TIC study of the surfaces showed that the height of most steps varies from 20 to $150 \mathrm{~nm}$, with a mean of 50-60 nm (Figure 6a-c). Single macrosteps have a height of up to 5-6 $\mu \mathrm{m}$.

Upon more intensive diamond dissolution under more oxidizing conditions (runs Ud-4 and Ud-5), surfaces with rounded step relief were formed at the octahedron edges (Figure $5 c, d$ ). The structure of these surfaces can be characterized as an alternation of rough-stepped relief with relatively smooth rounded areas and very elongated hillocks. Rounded, relatively smooth areas of the surfaces have fine striation; the height of striation steps is not more than $20 \mathrm{~nm}$ (Figure $6 \mathrm{~d}-\mathrm{f}$ ), with a mean height being several nanometers. Macrosteps and elongated hillocks are up to $10 \mu \mathrm{m}$ thick. 

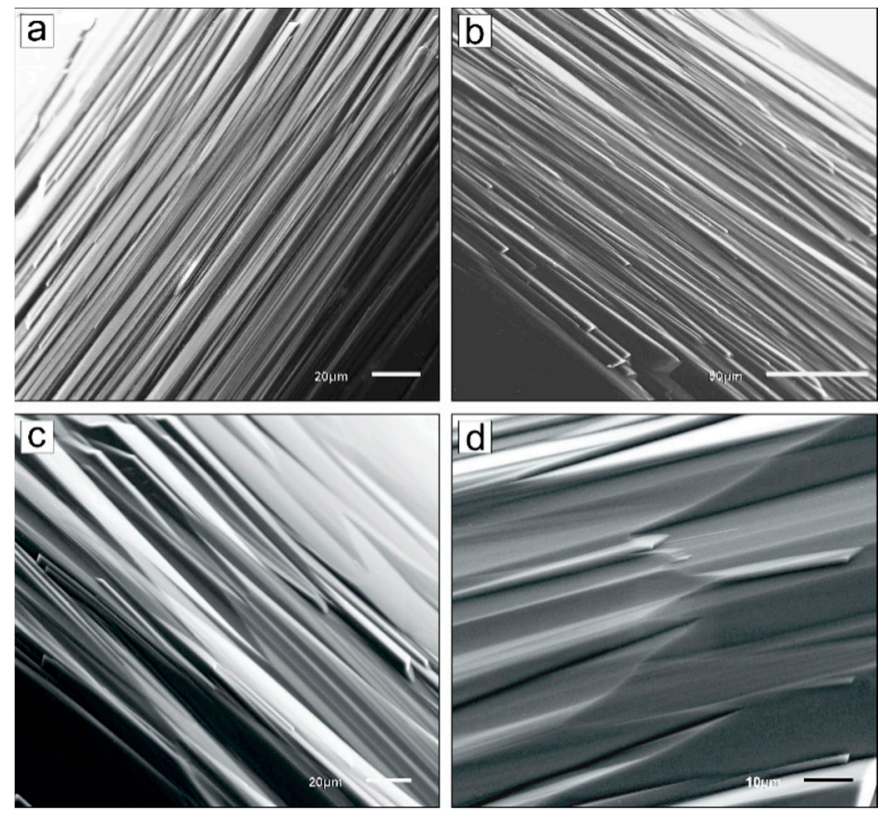

Figure 5. SEM micrographs of curved rough-relief surfaces formed in place of the octahedron edges: $(\mathbf{a}, \mathbf{b})$ run $U d-6$; (c) run $U d-4$; and (d) run $U d-5$.
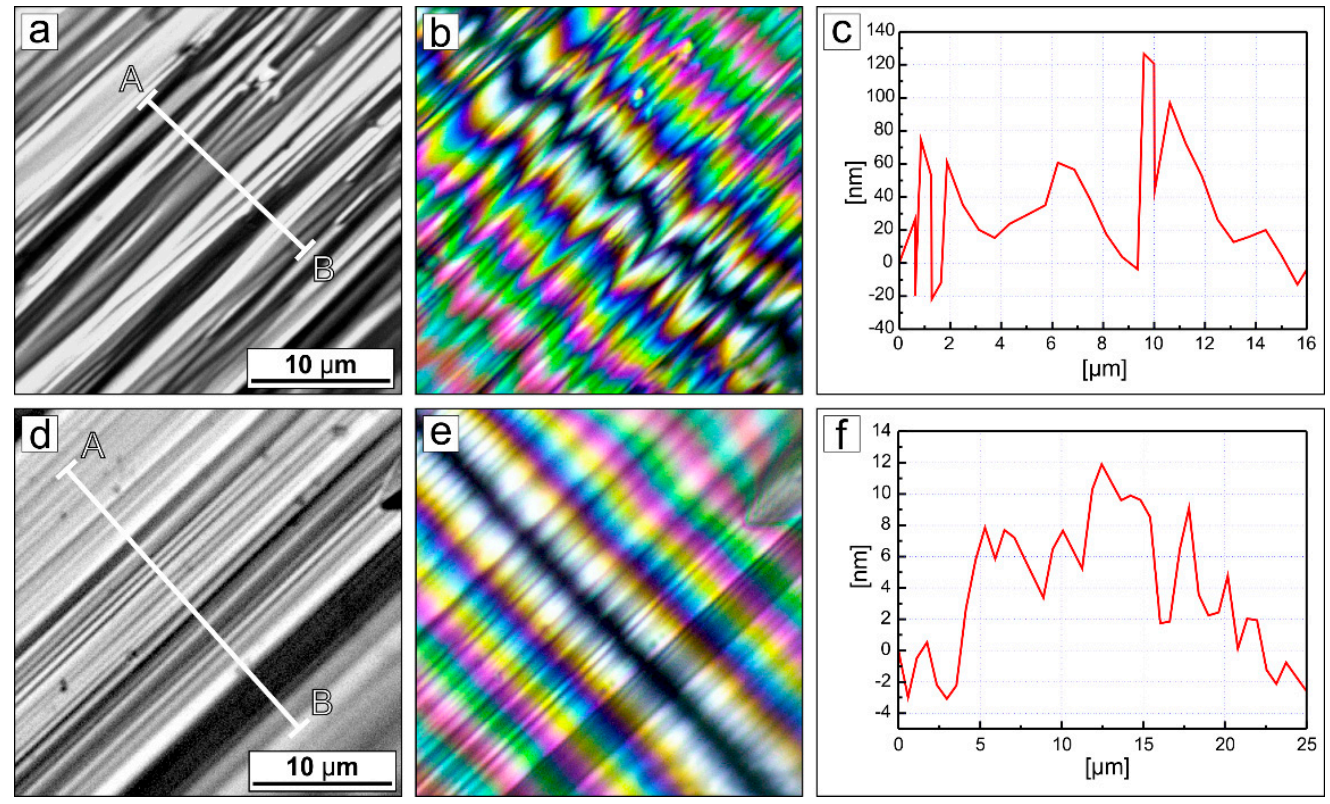

Figure 6. Optical micrographs (a,d), TIC images (b,e), and cross-sectional profiles $(\mathbf{c}, \mathbf{f})$ of surface microrelief of curved surfaces formed in place of the octahedron edges: (a) run Ud-6; (b) run Ud-5.

\section{Discussion}

\subsection{Trigons on Natural Diamonds}

Negatively oriented triangular pits, the so-called negative trigons, are almost always present on the $\{111\}$ faces of natural diamonds. The walls of trigons are usually stepped and they correspond to a series of trisoctahedra faces. According to the data of a goniometric study of natural diamond crystals from kimberlite pipes of Yakutia, the structure of trigons can involve almost all possible trigon-trioctahedra, with the most common faces being $\{998\},\{775\},\{221\},\{441\}$, and $\{661\}$ [32]. Based on goniometric measurements of trigons on diamonds from the Ural placers, A.A. Kukharenko [33] reported a slightly 
different set of the most common trisoctahedron faces. These are mainly trisoctahedrons: $\{887\},\{776\}$, $\{665\},\{554\}$, and $\{443\}$. However, given light diffraction inevitably occurring upon light reflection from thin-stepped surfaces, simple forms observed using optical goniometry cannot be considered really existing. More reliable information about the trigon structure is obtained using interference methods. With the use of multibeam interferometry has been shown that the walls of shallow p.b.trigons form an $\alpha(111)$ angle of $5^{\prime}$ to $2.5^{\circ}$ with the $\{111\}$ face $[23,31]$. Sometimes, step trigons, whose walls correspond to the $\{332\}$ faces $\left(\alpha_{(111)}=10^{\circ}\right)$, are observed [34]. Steep-wall non-stepped f.b.trigons are formed by the $\{111\}$ faces only [35].

The structure of trigons on natural diamonds can be studied in more detail using atomic force microscopy (AFM). Y. Fedortchouk [28] presented data on the study of trigons on three crystals of diamond from Ekati Diamond Mine kimberlites using AFM. It was found that p.b.trigons from 3 to $40 \mu \mathrm{m}$ in size have $\alpha_{(111)}$ from $3^{\circ}$ to $5^{\circ}$, which can correspond to simple Miller indices-\{998\}, \{887\}, $\{776\}$, and $\{665\}$. According to AFM measurements, walls of f.b.trigons of up to $40 \mu \mathrm{m}$ in size have $\alpha_{(111)}=7^{\circ}, 9^{\circ}, 17^{\circ}, 19^{\circ}$, and $23^{\circ}$ [28]. Given the measurement accuracy, these inclination angles may correspond to $\{443\},\{332\},\{944\},\{552\}$, and $\{331\}$ faces. Comparison of the results obtained by different measurement methods demonstrates good agreement for the inclination angle of negative trigon walls.

Thus, several types of negative trigons are formed on the $\{111\}$ faces of diamond crystals during natural resorption: (1) shallow trigons, primarily point-bottomed, with sidewalls having $\alpha_{(111)}$ from $5^{\prime}$ to $5^{\circ}$; (2) flat-bottomed stepped trigons confined by walls with $\alpha_{(111)}$ from $7^{\circ}$ to $23^{\circ}$; and (3) flat-bottomed non-stepped trigons composed exclusively of $\{111\}$ faces. An unambiguous relationship between p.b.trigons and dislocations was revealed using X-ray topography [21-23] and photoelasticity [24] techniques. All dislocations associated with trigons were found to be rectilinear and full edge dislocations or dislocations with a significant edge component [24].

It is considered unambiguously proven that trigons are formed during natural dissolution of diamond, and, therefore, they are etch pits. The inclination of etch pit walls is determined by the ratio of normal and tangential dissolution rates: $\operatorname{tg} \alpha=\mathrm{V}_{\mathrm{N}} / \mathrm{Vt}$, where $\mathrm{V}_{\mathrm{N}}$ is the dissolution rate component perpendicular to the surface, i.e., dissolution along the dislocation line, and $\mathrm{Vt}$ is the rate of dissolution parallel to the surface. $\mathrm{Vt}$ is controlled by the rate of step propagation along the surface. This issue is most thoroughly addressed in [36-38]. The application of theoretical models to trigonal pits on diamond was recently demonstrated in [20]. The rate ratio and, therefore, the inclination of etch pit walls depend on many parameters. For example, it was experimentally demonstrated that the inclination of pits walls on diamond may depend both on external parameters (medium composition, temperature, etching time, and oxygen fugacity) and on the features of diamond, such as the type of defects on which etch pits form $[39,40]$ and content of impurities in diamond crystals [41,42]. Under constant etching conditions (medium composition, temperature, etc.), the tangential dissolution rate, $\mathrm{Vt}$, is constant. In this case, the inclination of etch pit sidewalls is mainly controlled by the dissolution rate along the dislocation line $\left(\mathrm{V}_{\mathrm{N}}\right)$. If etching conditions are changed, the tangential etch rate also changes. For this reason, etch pits at the same dislocations have different inclinations. In this respect, of great interest are studies of diamond etching. For example, etch pits on $\{100\}$ diamond faces, which are formed with participation of oxygen or water vapor, have a wall inclination angle of 3-7 $7^{\circ}[43,44]$. Upon diamond etching with predominantly hydrogen plasma, etch pits of the same shape are formed on the $\{100\}$ faces, but the sidewall inclination angle amounts to $21-31^{\circ}$ [45]. In addition, the shape and inclination of etch pit sidewalls were demonstrated to depend on oxygen fugacity $[17,26]$. Therefore, the inclination of etch pit sidewalls may be an indicator of etching conditions. In this regard, the experimental reproduction of etching pits similar to natural trigons may indicate the similarity of the experimental parameters with the conditions of resorption of natural diamond.

The features of trigonal etch pits have received little attention in most experimental studies of diamond etching. Usually, researchers confine themselves to describing the shape and orientation of trigonal pits. Table 2 shows the data from studies on diamond dissolution at high temperatures and pressures, in which have investigated trigons in detail. The presented data indicate that etch pits on 
the $\{111\}$ faces, which were produced by diamond dissolution in water-bearing carbonate and silicate melts in previous works $[13,16,20]$ and in the present work, most closely correspond to trigons on natural diamonds. This suggests that water-bearing carbonate and silicate melts and P,T-conditions quite accurately reproduce natural diamond resorption at mantle conditions and during diamond transportation to the Earth's surface.

Table 2. Experimental conditions of runs and characteristics of experimentally obtained and natural trigons on the $\{111\}$ faces of diamond crystals.

\begin{tabular}{|c|c|c|c|c|c|}
\hline Refer. & $\begin{array}{l}\text { Composition of the } \\
\text { Etchant }\end{array}$ & $\begin{array}{c}\text { P, } \\
\text { GPa }\end{array}$ & $\begin{array}{l}{ }^{\mathrm{T}}, \\
{ }^{\circ} \mathrm{C}\end{array}$ & $\begin{array}{c}\alpha_{(111)} \\
\text { f.b.Trigons }\end{array}$ & $\begin{array}{c}\alpha_{(111)} \\
\text { p.b.Trigons }\end{array}$ \\
\hline [28] & $\mathrm{CaCO}_{3}+\mathrm{SiO}_{2}$ & 1 & $1150-1350$ & \multirow{2}{*}{$\begin{array}{c}\text { P.t. } 6^{\circ}, 10^{\circ}, 11^{\circ}, 15^{\circ}, 19^{\circ} \\
10-11^{\circ}, 15-16^{\circ}, 19-23^{\circ}, \\
43^{\circ}\end{array}$} & P.t. $6^{\circ}, 8^{\circ}, 10^{\circ}, 12^{\circ}$ \\
\hline [28] & $\mathrm{Mg}(\mathrm{OH})_{2}$ & 1 & $1150-1350$ & & $11^{\circ}, 19^{\circ}$ \\
\hline [20] & \multirow{3}{*}{$\begin{array}{c}\mathrm{H}_{2} \mathrm{O} \pm \mathrm{MgO} \pm \mathrm{SiO}_{2} \\
\text { basalt }+\mathrm{H}_{2} \mathrm{O} \\
\text { lamproite } \\
\mathrm{CaCO}_{3}\end{array}$} & $1-3$ & $1150-1400$ & $0.6^{\circ}$ to $67^{\circ}$ & $0.5^{\circ}$ to $43^{\circ}$ \\
\hline [13] & & $2.5-5.5$ & $1100-1450$ & \multicolumn{2}{|c|}{$1-2^{\circ}, 6-9^{\circ}, 11-14^{\circ}, 15-18^{\circ}, 19-22^{\circ}$} \\
\hline [27] & & 7.0 & $1700-1750$ & P.t. $5^{\circ}, 13^{\circ}$ & No trigons \\
\hline [18] & $\mathrm{Na}_{2} \mathrm{CO}_{3}+\mathrm{CO}_{2}$ & 5.7 & 1400 & P.t. $11.5^{\circ}, 19.5^{\circ}, 23.5^{\circ}$ & P.t. $19.5^{\circ}, 23.5^{\circ}$ \\
\hline [18] & $\mathrm{CaMg}\left(\mathrm{CO}_{3}\right)_{2}+\mathrm{CO}_{2}$ & 7.5 & 1600 & P.t. $11.5^{\circ}, 19.5^{\circ}, 23.5^{\circ}$ & P.t. $19.5^{\circ}, 23.5^{\circ}$ \\
\hline [18] & $\mathrm{Na}_{2} \mathrm{CO}_{3}+\mathrm{H}_{2} \mathrm{O}$ & 5.7 & 1400 & \multicolumn{2}{|c|}{$1-2^{\circ}, 7.5^{\circ}, 12.5^{\circ}, 16^{\circ}, 20.5^{\circ}$} \\
\hline [16] & $\begin{array}{c}\mathrm{CaMgSi}_{2} \mathrm{O}_{4}+\mathrm{H}_{2} \mathrm{O} \\
\mathrm{CaCO}_{3}+\mathrm{H}_{2} \mathrm{O}\end{array}$ & 5.7 & 1400 & $7^{\circ}, 11^{\circ}, 16^{\circ}, 21^{\circ}, 60^{\circ} 32^{\prime}$ & $1^{\circ}-2^{\circ}$ \\
\hline Present work & Kimberlite $+\mathrm{H}_{2} \mathrm{O}$ & 5.7 & 1400 & $1^{\circ}-2.5^{\circ}$ and $10^{\circ}$ & $0.5^{\circ}-3.0^{\circ}$ \\
\hline$[23,28,31,35]$ & \multicolumn{3}{|c|}{ Natural resorption of diamond } & $\begin{array}{c}7^{\circ}, 10^{\circ}, 17^{\circ}, 19^{\circ}, 23^{\circ}, \\
60^{\circ} 32^{\prime}\end{array}$ & $\begin{array}{l}5^{\prime}-2.5^{\circ} \\
3^{\circ}-5^{\circ}\end{array}$ \\
\hline
\end{tabular}

P.t.-positively oriented trigons.

Our experiments showed that upon diamond dissolution in a water-bearing kimberlite melt at $\mathrm{P}=6.3 \mathrm{GPa}$ and $\mathrm{T}=1400{ }^{\circ} \mathrm{C}$ and oxygen fugacity in the range from $\mathrm{ReReO}_{2}$ to $\mathrm{MH}$ buffer does not significantly affect the trigonal sidewall inclination. However, when diamond dissolves under conditions of oxygen fugacity near the MH buffer, a larger number of large flat-bottom trigons are formed.

\subsection{Tetrahexahedroid Surfaces on Natural Diamonds}

The tetrahexahedroid surfaces on natural diamonds have been unambiguously revealed to form during natural resorption. Apparently, depending on the resorption conditions and internal structure features, the rounded surfaces of natural diamonds have different sculptures. The most common sculpture types are as follows: Macroscopically smooth, glossy surfaces; stepped relief with various intensities of sheaf-like striation, from thin-stepped relief to rounded-stepped relief. Clusters of hillocks form block-type and drop-like surfaces, serrate relief, and shagreen microrelief.

In our experiments, we reproduced two relief types of the rounded tetrahexahedroid surfaces. Upon diamond dissolution in a water-bearing kimberlite melt at $\mathrm{fO}_{2}$ of the $\mathrm{Re}-\mathrm{ReO}_{2}$ buffer, the octahedron edges are truncated by surfaces with well-defined striation relatively uniformly spread through the entire tetrahexahedroid surface. However, when diamond is dissolved under more oxidizing conditions, the octahedron edges are truncated by roughly sculptured surfaces with alternation of rough-stepped relief, relatively smooth rounded areas, and very elongated hillocks. Possibly, wide variations in the relief of rounded natural diamonds from different deposits are associated with variations in redox conditions occurring during kimberlite magma formation in the Earth upper mantle. According to existing estimates, oxygen fugacity of kimberlite magma ranges from NNO-5 to NNO+6 [46]. This corresponds to oxygen fugacity in the range from approximately IW buffer to $\mathrm{MH}$ buffer at pressure of $6.0 \mathrm{GPa}$ and temperature of $1400{ }^{\circ} \mathrm{C}$. The run U-6 was carried out at an oxygen fugacity corresponding to $\mathrm{Re}-\mathrm{ReO}_{2}$ buffer, which is approximately one to two log units above the NNO buffer. Runs Ud-4 and Ud-5 occurred under more oxidizing conditions in the $\mathrm{fO}_{2}$ interval 
between $\mathrm{Re}-\mathrm{ReO}_{2}$ and $\mathrm{MH}$ buffers. These two experimental $\mathrm{fO}_{2}$ values were associated with two relief types of the rounded tetrahexahedroid surfaces typical of natural rounded diamonds. Thus, our data indicate wide variations in the morphology of diamonds upon dissolution at $\mathrm{fO}_{2}$ values typical of kimberlite magma.

\section{Conclusions}

We studied the morphology of diamond crystals partially dissolved in a water-bearing kimberlite melt at pressure of $6.3 \mathrm{GPa}$, temperature of $1400^{\circ} \mathrm{C}$, run time of $10 \mathrm{~h}$, and two oxygen fugacity values $\left(\mathrm{fO}_{2}\right.$ ) corresponding to the $\mathrm{Re}-\mathrm{ReO}_{2}$ buffer and near the $\mathrm{HM}$ buffer. The formed triangular etch pits on $\{111\}$ faces were found to be similar to negative trigons on natural diamond crystals in the shape and wall inclination angles. When diamond is dissolved under more oxidizing conditions, a greater amount of relatively large flat-bottomed trigons form. Furthermore, two experimental $\mathrm{fO}_{2}$ values are associated with two relief types of the rounded tetrahexahedroid surfaces characteristic of natural rounded diamonds. When diamond is dissolved in a water-bearing kimberlite melt at $\mathrm{fO}_{2}$ of the $\mathrm{Re}-\mathrm{ReO}_{2}$ buffer, the octahedron edges are truncated by surfaces with well-defined striation through the entire tetrahexahedroid surface. When diamond is dissolved under more oxidizing conditions, the octahedron edges are truncated by rough-sculptured surfaces with alternation of rough-stepped relief, relatively smooth rounded areas, and very elongated hillocks. These findings suggest that the surface microrelief of rounded natural diamonds is an indicator of $\mathrm{fO}_{2}$ of natural diamond resorption.

Author Contributions: Conceptualization, A.F.K.; methodology, A.F.K. and A.G.S.; investigation, A.F.K., A.G.S. and D.V.N.; visualization, A.F.K. and D.V.N.; writing-original draft preparation, A.F.K. and A.G.S.; writing-review \& editing, A.F.K. and A.G.S. All authors have read and agreed to the published version of the manuscript.

Funding: This research was funded by the Russian Science Foundation, Grant number 19-77-10023.

Conflicts of Interest: The authors declare no conflict of interest. The funders had no role in the design of the study; in the collection, analyses, or interpretation of data; in the writing of the manuscript, or in the decision to publish the results.

\section{References}

1. Moore, M.; Lang, A.R. On the origin of the rounded dodecahedral habit of natural diamond. J. Cryst. Growth 1974, 26, 133-139. [CrossRef]

2. Orlov, Y.L. The Mineralogy of Diamond; John Wiley: New York, NY, USA, 1977; 235p.

3. Robinson, D.N. The characteristics of natural diamond and their interpretation. Miner. Sci. Eng. 1978, 10, 55-72.

4. Sunagawa, I. Morphology of natural and synthetic diamond crystals. In Materials Science of the Earth's Interior; Sunagawa, I., Ed.; Terra Scientific Publishing: Tokyo, Japan, 1984; pp. 303-330.

5. Mitchell, R.H.; Giuliani, A.; O'Brien, H. What is a kimberlite? Petrology and mineralogy of hypabyssal kimberlites. Elements 2019, 15, 381-386. [CrossRef]

6. Becker, M.; Le Roex, A.P. Geochemistry of South African on- and off-craton, Group I and Group II kimberlites: Petrogenesis and source region evolution. J. Petrol. 2006, 47, 673-703. [CrossRef]

7. Kopylova, M.G.; Matveev, S.; Raudsepp, M. Searching for parental kimberlite melt. Geochim. Cosmochim. Acta 2007, 71, 3616-3629. [CrossRef]

8. Kjarsgaard, B.A.; Pearson, D.G.; Tappe, S.; Nowell, G.M.; Dowall, D.P. Geochemistry of hypabyssal kimberlites from Lac de Gras, Canada: Comparisons to a global database and applications to the parent magma problem. Lithos 2009, 112, 236-248. [CrossRef]

9. Kamenetsky, M.B.; Sobolev, A.V.; Kamenetsky, V.S.; Maas, R.; Danyushevsky, L.V.; Thomas, R.; Pokhilenko, N.P.; Sobolev, N.V. Kimberlite melts rich in alkali chlorides and carbonates: A potent metasomatic agent in the mantle. Geology 2004, 32, 845-848. [CrossRef]

10. Kamenetsky, V.S.; Kamenetsky, M.B.; Golovin, A.V.; Sharygin, V.V.; Maas, R. Ultrafresh salty kimberlite of the Udachnaya-East pipe (Yakutia, Russia): A petrological oddity or fortuitous discovery? Lithos 2012, 152, 173-186. [CrossRef] 
11. Arima, M.; Nakayama, K.; Akaishi, M.; Yamaoka, S.; Kanda, H. Crystallization of diamond from a silicate melt of kimberlite composition in high-pressure and high-temperature experiments. Geology 1993, 21, 968-970. [CrossRef]

12. Palyanov, Y.N.; Sokol, A.G.; Khokhryakov, A.F.; Kruk, A.N. Conditions of diamond crystallization in kimberlite melt: Experimental data. Russ. Geol. Geophys. 2015, 56, 196-210. [CrossRef]

13. Khokhryakov, A.F.; Pal'yanov, Y.N. The morphology of diamond crystals, dissolved in the water containing silicate melts. Mineral. Zournal 1990, 12, 14-23. (In Russian)

14. Kozai, Y.; Arima, M. Experimental study on diamond dissolution in kimberlitic and lamproitic melts at 1300-1420 ${ }^{\circ} \mathrm{C}$ and $1 \mathrm{GPa}$ with controlled oxygen partial pressure. Am. Mineral. 2005, 90, 1759-1766. [CrossRef]

15. Fedortchouk, Y.; Canil, D.; Semenets, E. Mechanisms of diamond oxidation and their bearing on the fluid composition in kimberlite magmas. Am. Mineral. 2007, 92, 1200-1212. [CrossRef]

16. Khokhryakov, A.F.; Palyanov, Y.N. The evolution of diamond morphology in the process of dissolution: Experimental data. Am. Mineral. 2007, 92, 909-917. [CrossRef]

17. Fedortchouk, Y.; Canil, D. Diamond oxidation at atmospheric pressure: Development of surface features and the effect of oxygen fugacity. Eur. J. Mineral. 2009, 21, 623-635. [CrossRef]

18. Khokhryakov, A.F.; Palyanov, Y.N. Influence of the fluid composition on diamond dissolution forms in carbonate melts. Am. Mineral. 2010, 95, 1508-1514. [CrossRef]

19. Sokol, A.G.; Khokhryakov, A.F.; Palyanov, Y.N. Composition of primary kimberlite magma: Constraints from melting and diamond dissolution experiments. Contrib. Mineral. Petrol. 2015, 170, 26. [CrossRef]

20. Zhang, Z.; Fedortchouk, Y.; Hanley, J.J. Evolution of diamond resorption in a silicic aqueous fluid at 1-3 GPa: Application to kimberlite emplacement and mantle metasomatism. Lithos 2015, 227, 179-193. [CrossRef]

21. Frank, F.C.; Lang, A.R. Observation by X-ray diffraction on dislocation in a diamond. Phil. Mag. 1959, 4, 383-386. [CrossRef]

22. Frank, F.C.; Lang, A.R. X-ray topography of diamond. In Physical Properties of Diamond; Berman, R., Ed.; Clarendon Press: Oxford, UK, 1965; pp. 69-115.

23. Lang, A.R. Dislocation in diamond and the origin of trigons. Proc. R. Soc. Lond. A 1964, 278, $234-242$. [CrossRef]

24. van Enckevort, W.J.P.; Seal, M. Stress birefringence microscopy of dislocations in type-Ia natural diamond. Phil. Mag. 1988, 57, 939-954. [CrossRef]

25. Khokhryakov, A.F.; Palyanov, Y.N. Effect of crystal defects on diamond morphology during dissolution in the mantle. Am. Mineral. 2015, 100, 1528-1532. [CrossRef]

26. Yamaoka, S.; Kanda, H.; Setaka, N. Etching of diamond octahedron at high temperatures and pressure with controlled oxygen partial pressure. J. Mater. Sci. 1980, 15, 332-336. [CrossRef]

27. Khokhryakov, A.F.; Palyanov, Y.N. Dissolution forms of diamond crystals in $\mathrm{CaCO}_{3}$ melt at 7 GPa. Russ. Geol. Geophys. 2000, 41, 682-687.

28. Fedortchouk, Y. Diamond resorption features as a new method for examining conditions of kimberlite emplacement. Contrib. Mineral. Petrol. 2015, 170, 36. [CrossRef]

29. Fedortchouk, Y. A new approach to understanding diamond surface features based on a review of experimental and natural diamond studies. Earth-Sci. Rev. 2019, 193, 45-65. [CrossRef]

30. Brey, G.P.; Bulatov, V.K.; Girnis, A.V. Melting of K-rich carbonated peridotite at 6-10 GPa and the stability of K-phases in the upper mantle. Chem. Geol. 2011, 281, 333-342. [CrossRef]

31. Frank, F.C.; Puttic, K.E.; Wilks, E.M. Etch pits and trigons of diamond: I. Phil. Mag. 1958, 3, $1262-1279$. [CrossRef]

32. Bartoshinsky, Z.V.; Kvasnitsa, V.N. Crystal Morphology of Diamond from Kimberlites; Naukova Dumka: Kiev, Ukraine, 1991; 172p. (In Russian)

33. Kuharenko, A.A. Diamonds of the Urals; Gosgeoltekhizdat: Moscow, Russia, 1955; 515p. (In Russian)

34. Bedarida, F. Micromorphology of (111) faces in diamond twins. Acta Cryst. 1967, 23, 708-710. [CrossRef]

35. Wilks, E.M. Step-sided trigons on diamonds. Philos. Mag. 1961, 69, 1089-1092. [CrossRef]

36. Angus, J.C.; Dyble, T.J. Etching models for a $\{111\}$ diamond surface: Calculation of trigon slopes. Surf. Sci. 1975, 50, 157-177. [CrossRef]

37. Heimann, R.B. Auflösung von Kristallen: Theorie und Techniche Anwendung; Springer: New York, NY, USA, $1975 ; 270$ p. 
38. Sangwal, K. Etching of Crystals: Theory, Experiment, and Application; Elsevier: Amsterdam, The Netherlands, 1987; 518p.

39. Khokhryakov, A.F.; Palyanov, Y.N. Revealing of dislocations in diamond crystals by the selective etching method. J. Cryst. Growth 2006, 293, 469-474. [CrossRef]

40. Khokhryakov, A.F.; Palyanov, Y.N. Revealing of planar defects and partial dislocations in large synthetic diamond crystals by the selective etching. J. Cryst. Growth 2007, 306, 458-464. [CrossRef]

41. Khokhryakov, A.F.; Palyanov, Y.N. Effect of nitrogen impurity on etching of synthetic diamond crystals. J. Cryst. Growth 2015, 430, 71-74. [CrossRef]

42. Khokhryakov, A.F.; Palyanov, Y.N.; Borzdov, Y.M.; Kozhukhov, A.S.; Sheglov, D.V. Dislocation etching of diamond crystals grown in Mg-C system with the addition of silicon. Diam. Relat. Mater. 2018, 88, 67-73. [CrossRef]

43. de Theije, F.K.; Roy, O.; van der Laag, N.J.; van Enckevort, W.J.P. Oxidative etching of diamond. Diamond Relat. Mater. 2000, 9, 929-934. [CrossRef]

44. Tsubouchi, N.; Mokunoa, Y.; Shikata, S. Characterizations of etch pits formed on single crystal diamond surface. Diam. Relat. Mater. 2016, 63, 43-46. [CrossRef]

45. Ivanov, O.A.; Muchnikov, A.B.; Chernov, V.V.; Bogdanovn, S.A.; Vikharev, A.L.; Butler, J.E. Experimental study of hydrogen plasma etching of (100) single crystal diamond in a MPACVD reactor. Mater. Lett. 2015, 151, 115-118. [CrossRef]

46. Canil, D.; Bellis, A.J. Ferric iron in $\mathrm{CaTiO}_{3}$ perovskite as an oxygen barometer for kimberlite magmas II: Applications. J. Petrol. 2007, 48, 231-252. [CrossRef]

(C) 2020 by the authors. Licensee MDPI, Basel, Switzerland. This article is an open access article distributed under the terms and conditions of the Creative Commons Attribution (CC BY) license (http://creativecommons.org/licenses/by/4.0/). 